\title{
Inhaled ciclesonide versus inhaled budesonide or inhaled beclomethasone or inhaled fluticasone for chronic asthma in adults:
} a systematic review

\author{
Matthew J Dyer ${ }^{1}$, David MG Halpin ${ }^{2}$ and Ken Stein*3
}

Address: ${ }^{1}$ Clinical Research Assistant, Peninsula Medical School, University of Exeter, UK, ${ }^{2}$ Consultant Physician \& Senior Lecturer in Respiratory Medicine, Royal Devon and Exeter Hospital, Exeter, UK and ${ }^{3}$ Senior Clinical Lecturer in Public Health, Peninsula Medical School, University of Exeter, UK

Email: Matthew J Dyer - matthew.dyer@pentag.nhs.uk; David MG Halpin - david.halpin@rdehc-tr.swest.nhs.uk; Ken Stein* - ken.stein@exeter.ac.uk

* Corresponding author

Published: 05 June 2006

BMC Family Practice 2006, 7:34 doi:10.1/86/147I-2296-7-34
Received: 25 November 2005

Accepted: 05 June 2006

This article is available from: http://www.biomedcentral.com/I47/-2296/7/34

(c) 2006 Dyer et al; licensee BioMed Central Ltd.

This is an Open Access article distributed under the terms of the Creative Commons Attribution License (http://creativecommons.org/licenses/by/2.0), which permits unrestricted use, distribution, and reproduction in any medium, provided the original work is properly cited.

\begin{abstract}
Background: Ciclesonide is a new inhaled corticosteroids licensed for the prophylactic treatment of persistent asthma in adults. Currently beclomethasone dipropionate, budesonide and fluticasone propionate are the most commonly prescribed inhaled corticosteroids for the treatment of asthma but there has been no systematic review comparing the effectiveness and safety ciclesonide to these agents. We therefore aimed to systematically review published randomised controlled trials of the effectiveness and safety of ciclesonide compared to alternative inhaled corticosteroids in people with asthma.

Methods: We performed literature searches on MEDLINE, EMBASE, PUBMED, the COCHRANE LIBRARY and various Internet evidence sources for randomised controlled trials or systematic reviews comparing ciclesonide to beclomethasone or budesonide or fluticasone in adult humans with persistent asthma. Data was extracted by one reviewer.

Results: Five studies met the inclusion criteria. Methodological quality was variable. There were no trials comparing ciclesonide to beclomethasone. There was no significant difference between ciclesonide and budesonide or fluticasone on the following outcomes: lung function, symptoms, quality of life, airway responsiveness to a provoking agent or inflammatory markers. However, the trials were very small in size, increasing the possibility of a type II error. One trial demonstrated that the combined deposition of ciclesonide (and its active metabolite) in the oropharynx was $47 \%$ of that of budesonide while another trial demonstrated that the combined deposition of ciclesonide (and its active metabolite) in the oropharynx was $53 \%$ of that of fluticasone. One trial demonstrated less suppression of cortisol in overnight urine collection after ciclesonide compared to fluticasone (geometric mean fold difference $=1.5, \mathrm{P}<0.05$ ) but no significant difference in plasma cortisol response.

Conclusion: There is very little evidence comparing CIC to other ICS, restricted to very small, phase II studies of low power. These demonstrate $\mathrm{CIC}$ has similar effectiveness and efficacy to FP and BUD (though equivalence is not certain) and findings regarding oral deposition and HPA suppression are inconclusive. There is no direct comparative evidence that $\mathrm{CIC}$ causes fewer side effects since none of the studies reported patient-based outcomes.
\end{abstract}




\section{Background}

Inhaled corticosteroids (ICS) have a central role in the treatment of asthma. They are the most effective prophylactic agents available, particularly in patients with mild to moderate asthma and persistent symptoms[1] and are recommended for most adult patients with chronic asthma whose symptoms are not controlled by inhaled short acting $\beta 2$ agonists [2-4]. Regular treatment with corticosteroids reduces exacerbations, improves control of symptoms and lung function, while reducing hospital admissions and deaths from asthma[1,5]. However, prolonged use in persistent asthma and increased doses in severe cases may result in suppression of the hypothalamic pituitary adrenal (HPA) system with concern that this might cause growth impairment in children (including premature closure of the epiphyses of long bones), disturbed glucose tolerance, decreased mineralisation of bone (increasing the risk of fractures), ocular problems such as glaucoma and cataracts as well as thinning of the skin [6-8]. Local adverse affects, even at low doses may include dysphonia, pharyngitis and oral candidiasis[2,9].

The mainstay of ICS treatment has been with three agents: beclomethasone dipropionate (BDP), budesonide (BUD) and, more recently, fluticasone propionate (FP). All these agents are similar chemically and structurally but have different pharmacodynamic properties resulting in different clinical effects[10]. A Cochrane review of 48 studies comparing the three agents concluded that FP given at half the daily dose of BDP or BUD leads to small improvement in measures of airway calibre (peak expiratory flow (PEF) and forced expiratory volume in one second (FEV1) while at the same daily dose FP appears to have a higher risk of side effects than BDP or BUD[10].

Ciclesonide (CIC) is a new ICS, manufactured by Altana Pharma Ltd. CIC is licensed only for the treatment of persistent asthma in adults (18 years older) and is delivered via a hydrofluoroalkane metered-dose inhaler (HFA MDI) in 40,80 and $160 \mathrm{mcg}$ formulations. The recommended starting dose is $160 \mathrm{mcg}$ given in the evening, with reduction to $80 \mathrm{mcg}$ for maintenance[11]. These doses are "exactuator", i.e. the dose expelled, as opposed to "ex-valve" i.e. the actual dose contained in the inhaler (for consistency, throughout this review ex-valve doses are used for all inhalers).

Ciclesonide has little anti-inflammatory activity itself and requires cleavage by endogenous carboxyl esterases in the lung, which creates the active metabolite desisobutrylciclesonide (des-CIC)[12]. This targets activity at the desired location. Des-Ciclesonide undergoes rapid hepatic metabolism into inactive metabolites on leaving the lung[13]. These factors, together with the fact that ciclesonide has very low oral bioavailability due to almost complete first pass metabolism[14] would seem to create conditions favouring the maximisation of therapeutic effect in the lung and minimisation of the risk of systemic adverse effects.

Given that ciclesonide is being actively marketed as an alternative to alternative to other inhaled corticosteroids, our objective in this study was to systematically review published randomised controlled trials of the effectiveness and safety of ciclesonide compared to alternative inhaled corticosteroids in people with asthma.

\section{Methods}

\section{Search strategy}

We performed literature searches on MEDLINE (from 1951), EMBASE, PUBMED and the COCHRANE LIBRARY (The Cochrane Central Register of Controlled Trials) using the following terms:

Ciclesonide, Alvesco, Budesonide, Pulmicort, Beclomethasone, Becotide, Becloforte, Fluticasone, Flixotide

We imported abstracts of citations from this search into an electronic database. We also searched for "ciclesonide" and "alvesco" on the web sites of the following internet evidence sources:

- Drug and Therapeutics Bulletin http://www.dtb.org.uk/ dtb

- Succinct and Timely Evaluated Evidence Reviews (STEER)

- Aggressive Research Intelligence Facility http:// www.bham.ac.uk/arif/index.html

- West Midlands Health Technology Assessment Collaboration http://www.pcpoh.bham.ac.uk/publichealth/ wmhtac/

- International Network of Agencies for Health Technology Assessment http://www.inahta.org

- Canadian Coordinating Office for Health Technology Assessment http://www.ccohta.ca

Only the CCOHTA site yielded a result: a non-systematic review. This was subsequently excluded.

Reference lists of retrieved articles were scrutinized for further studies but yielded no additional papers.

Titles and abstracts were sifted by two reviewers and prior to retrieval of full articles, the two reviewers independently assessed papers for inclusion. Cases of disagreement 
were resolved by discussion (or, where necessary, delayed until retrieval of the full text). All full text papers retrieved were again assessed by the two independent reviewers for inclusion and methodological quality (see Appendix 1). There was no blinding to authors' names or institutions and no scoring system (such as the Jadad score) was used. Data were extracted by one reviewer.

\section{Inclusion criteria for considering studies Participants}

Studies in human adults (i.e. people aged 18 and over) with a diagnosis of chronic asthma were included. We did not consider studies concerning acute asthma, chronic obstructive pulmonary disease or allergic rhinitis.

\section{Intervention}

Studies concerning only inhalation of ciclesonide and excluded those involving oral, nasal or intravenous routes.

\section{Comparators}

Studies that compared ciclesonide to either budesonide or beclomethasone or fluticasone and excluded studies comparing to placebo only or to other asthma treatments.

\section{Outcome measures}

we considered all reported outcomes although prominence was given to patient based outcomes.

\section{Study design}

Prospective, randomized, controlled trials and or reviews that were clearly systematic and carried out since the beginning of 2004. Studies published only as abstracts were included only if they contained sufficient methodological detail to enable critical appraisal. We considered studies in all languages.

\section{Results}

\section{Search results}

Table 1 shows the results of the search. A total of five RCTs were included (details in Table 2) [15-19]. No reviews or abstracts qualified for inclusion. Two RCTs compared CIC to BUD $[15,19]$ and three RCTs compared CIC to FP [1618]. The Kanniess et al study[19] was the only RCT not apparently sponsored by a pharmaceutical company manufacturing CIC.

\section{Quality of the evidence}

All papers were critically appraised for methodological quality based on the criteria shown in Table 3. All trials involved small numbers (the largest number of participants completing the study being 19[18]) and were of very short duration (maximum four weeks). Three of the studies had drop-outs after randomization with attrition rates varying from $5.25 \%-30 \%$ [17-19]. In general, pop- ulations were similar, although two studies did not exclude smokers. Participants had mild asthma with mean FEV1 greater than $90 \%$ of the predicted value in three of the trials.

Three of the studies were cross-over trials and washout periods were all of appropriate length [17-19]. Nave et al and Richter et al were" within patient" trials, and therefore similar to a crossover design, but both treatments were given concurrently, presumably on the assumption that oropharyngeal deposition was independent of treatment but potentially confounded by short term changes in oropharyngeal conditions. There were no parallel studies. There was insufficient reporting to verify whether there was good balance at baseline in the crossover trials. In the Kanniess et al study there was also imbalance between the population as a whole before receiving CIC and the same population before receiving BUD.

Only one trial (Kanniess et al) was clearly double (or more) blinded. Lee, Fardon et al and Lee, Haggart et al it state that the inhalers were "masked" but it is not clear whether their identity was withheld from the treatment administrator or observer as well as the patient. None of the trials reported whether, or how, they concealed allocation of treatment within participants or methods for randomization. Overall there was no evidence of performance bias.

Only two trials (Lee, Fardon et al and Lee, Haggert et al) measured patient based outcomes as end points i.e. symptoms and QoL. All the others measured intermediate outcomes and any interpretation of these results will require an assessment of the degree to which these outcomes are clinically significant.

Some studies (e.g. Kanniess et al [19] and to some extent Lee, Fardon et al[17]) only reported pre and post treatment results within the same treatment (i.e. CIC or the comparator). Although the authors stated there was no significant difference between treatments, they showed no data or calculations.

\section{Outcomes measured in the trials}

Lung function tests

- FEV1, FVC, PEF etc.

Symptoms

- Symptom diary

- Use of rescue medication

Quality of Life 
Table I: Search Results Summary

\begin{tabular}{|c|c|c|c|c|c|c|c|c|c|}
\hline Search & Medline & Embase & PubMed & Cochrane & Internet & $\begin{array}{l}\text { Total no. of } \\
\text { papers } \\
\text { without } \\
\text { duplicates }\end{array}$ & Reviews & Abstracts & $\begin{array}{l}\text { Papers after } \\
\text { exclusion }\end{array}$ \\
\hline $\begin{array}{l}\text { (Ciclesonide } \\
\text { or Alvesco) } \\
\text { and } \\
\text { (Budesonide } \\
\text { or } \\
\text { Pulmicort) }\end{array}$ & 6 & 58 & 7 & 7 & 1 & 66 & $\begin{array}{l}4 \text { ( } 2 \text { are } \\
\text { duplicates } \\
\text { with the FP } \\
\text { search) }\end{array}$ & 5 & 2 \\
\hline $\begin{array}{l}\text { (Ciclesonide } \\
\text { or Alvesco) } \\
\text { and } \\
\text { (Beclometh } \\
\text { asone or } \\
\text { Becotide or } \\
\text { Becloforte) }\end{array}$ & I & 1 & 1 & 0 & 0 & 2 & 0 & 0 & 0 \\
\hline $\begin{array}{l}\text { (Ciclesonide } \\
\text { or Alvesco) } \\
\text { and } \\
\text { (Fluticasone } \\
\text { or Flixotide) }\end{array}$ & 4 & 56 & 4 & 4 & 0 & 62 & $\begin{array}{l}2 \text { (both are } \\
\text { duplicates } \\
\text { with the FP } \\
\text { search) }\end{array}$ & 3 & 3 \\
\hline
\end{tabular}

- Mini Asthma quality of life (QoL) questionnaire[20]

Airway responsiveness to provoking agent

- This is measured in terms of the concentration of inhaled provoking agent (adenosine monophosphate (AMP) or metacholine) required to cause a $20 \%$ fall in FEV1 (PC20). The initial dose is inhaled and the FEV1 measured subsequently. The dose is then doubled progressively until a $20 \%$ fall is recorded
Inflammatory markers

- Nitric oxide (NO) exhaled

- Inflammatory markers in the sputum

Hypothalamic-Pituitary-Adrenal (HPA) suppression (systemic toxicity)

- Plasma cortisol response to human corticotrophinreleasing factor (hCRF). This test has been shown to detect

Table 2: RCTs included in the review

\begin{tabular}{|c|c|c|c|c|c|}
\hline Author & Publisher & Sponsor & Study size & Duration & Comparator \\
\hline Nave et al, 2005 & $\begin{array}{l}\text { European Journal of } \\
\text { Clinical Pharmacology }\end{array}$ & ALTANA & 18 & $\begin{array}{l}\text { Measurements at } 0 \\
15,30,45 \text { and } 60 \text { mins }\end{array}$ & $\begin{array}{l}\text { CIC } 800 \text { mcg (HFA } \\
\text { MDI) od am Vs. BUD } \\
800 \text { mcg (turbohaler) } \\
\text { od am }\end{array}$ \\
\hline Richter et al, 2005 & $\begin{array}{l}\text { Journal of Clinical } \\
\text { Pharmacology }\end{array}$ & ALTANA & 18 & $\begin{array}{l}\text { Measurements at } 0 \text {, } \\
15,30,45 \text { and } 60 \text { mins }\end{array}$ & $\begin{array}{l}\text { CIC } 800 \text { mcg (HFA } \\
\text { MDI) od am Vs. FP } \\
\text { I000 mcg (HFA MDI) } \\
\text { od am }\end{array}$ \\
\hline Lee, Fardon et al, 2005 & Chest & AVENTIS & 14 & $\begin{array}{l}4 \text { weeks Crossover } \\
\text { with } 2 \text { week washout } \\
\text { period }\end{array}$ & $\begin{array}{l}\mathrm{ClC} 800 \text { mcg (HFA } \\
\text { MDI) bd Vs. FP I000 } \\
\text { mcg (HFA MDI) bd }\end{array}$ \\
\hline $\begin{array}{l}\text { Lee, Haggart et al, } \\
2004\end{array}$ & $\begin{array}{l}\text { British Journal of } \\
\text { Clinical Pharmacology }\end{array}$ & AVENTIS & 19 & $\begin{array}{l}4 \text { weeks Crossover } \\
\text { with } 2 \text { week washout } \\
\text { period }\end{array}$ & $\begin{array}{l}\text { ClC } 400 \text { mcg (HFA } \\
\text { MDI) od am Vs. FP } \\
250 \text { mcg (HFA MDI) } \\
\text { bd }\end{array}$ \\
\hline Kanniess et al, 200I & $\begin{array}{l}\text { Pulmonary } \\
\text { Pharmacology and } \\
\text { Therapeutics }\end{array}$ & None declared & 15 & $\begin{array}{l}2 \text { weeks (Cross over } \\
\text { study with at least } 3 \\
\text { week washout period) }\end{array}$ & $\begin{array}{l}\text { CIC } 400 \text { mcg (HFA } \\
\text { MDI) od am Vs. BUD } \\
400 \text { mcg (turbohaler) } \\
\text { od am }\end{array}$ \\
\hline
\end{tabular}


Table 3: RCT Methodological Characteristics

\begin{tabular}{|c|c|c|c|c|c|c|c|c|c|c|c|c|}
\hline Author & Year & Population & & Comp. & Duration & Conceal-ment & Blinding & & Random-isation & Attrition & Balance at baseline & Equal handling \\
\hline \multirow[t]{5}{*}{ Kanniess et al } & 2001 & No. completing & 15 & BUD & $\begin{array}{l}2 \text { weeks crossover } \\
3-8 \text { weeks washout }\end{array}$ & No info about allocation & Participant & Yes & Yes but no evidence of method & I (5.25\%) & no & yes \\
\hline & & Mean age & 33 & & & & Admin. & no & & & & \\
\hline & & Stable & yes & & & & Observer & yes & & & & \\
\hline & & $\begin{array}{l}\text { Non smokers } \\
\text { only }\end{array}$ & yes & & & & Analyst & $?$ & & & & \\
\hline & & $\begin{array}{l}\text { Mean FEVI \% } \\
\text { pred: }\end{array}$ & 94 & & & & & & & & & \\
\hline \multirow[t]{5}{*}{ Nave et al } & 2005 & No. completing & 18 & BUD & $\begin{array}{l}\text { Combined treatment } \\
\text { Oropharyngeal washings taken } \\
\text { at } 0 \text { mins on day } 1,15 \text { mins on } \\
\text { day } 2,30 \text { mins on day } 3,45 \text { mins } \\
\text { on day } 4 \text { and } 60 \text { mins on day } 5 .\end{array}$ & No info about allocation & Participant & no & Yes but no evidence of method & 0 & yes & yes \\
\hline & & Mean age & 33 & & & & Admin. & no & & & & \\
\hline & & Stable & yes & & & & Observer & no & & & & \\
\hline & & $\begin{array}{l}\text { Non smokers } \\
\text { only }\end{array}$ & no & & & & Analyst & $?$ & & & & \\
\hline & & $\begin{array}{l}\text { Mean FEVI \% } \\
\text { pred: }\end{array}$ & $?$ & & & & & & & & & \\
\hline \multirow[t]{5}{*}{$\begin{array}{l}\text { Lee, Fardon } \\
\text { et al }\end{array}$} & 2005 & No. completing & 14 & FP & $\begin{array}{l}4 \text { weeks crossover } 2 \text { weeks } \\
\text { washout }\end{array}$ & No info about allocation & Participant & yes & Yes but no evidence of method & $6(30 \%)$ & yes & yes \\
\hline & & Mean age & 47 & & & & Admin. & $?$ & & & & \\
\hline & & Stable & yes & & & & Observer & $?$ & & & & \\
\hline & & $\begin{array}{l}\text { Non smokers } \\
\text { only }\end{array}$ & yes & & & & Analyst & $?$ & & & & \\
\hline & & $\begin{array}{l}\text { Mean FEVI \% } \\
\text { pred: }\end{array}$ & 77 & & & & & & & & & \\
\hline \multirow[t]{5}{*}{$\begin{array}{l}\text { Lee, Haggart } \\
\text { et al }\end{array}$} & 2004 & No. completing & 19 & FP & $\begin{array}{l}4 \text { weeks crossover } 2 \text { weeks } \\
\text { washout }\end{array}$ & No info about allocation & Participant & yes & Yes but no evidence of method & $4(17.5 \%)$ & yes & yes \\
\hline & & Mean age & 45 & & & & Admin. & $?$ & & & & \\
\hline & & Stable & yes & & & & Observer & $?$ & & & & \\
\hline & & $\begin{array}{l}\text { Non smokers } \\
\text { only }\end{array}$ & yes & & & & Analyst & $?$ & & & & \\
\hline & & $\begin{array}{l}\text { Mean FEVI \% } \\
\text { pred: }\end{array}$ & 90 & & & & & & & & & \\
\hline \multirow[t]{5}{*}{ Richter et al } & 2005 & No. completing & 18 & FP & $\begin{array}{l}\text { Combined treatment } \\
\text { Treatement } 5-14 \text { days }(5 \\
\text { treatments in total at } 0,15,30, \\
45 \text { and } 60 \text { minutes). Minimum I } \\
\text { day washout }\end{array}$ & No info about allocation & Participant & no & Yes but no evidence of method & 0 & yes & yes \\
\hline & & Mean age & 37 & & & & Admin. & no & & & & \\
\hline & & Stable & yes & & & & Observer & no & & & & \\
\hline & & $\begin{array}{l}\text { Non smokers } \\
\text { only }\end{array}$ & no & & & & Analyst & $?$ & & & & \\
\hline & & $\begin{array}{l}\text { Mean FEVI \% } \\
\text { pred: }\end{array}$ & 91 & & & & & & & & & \\
\hline
\end{tabular}


impaired adrenal reserves in corticosteroid-treated patients[21].

- Urine cortisol

Oropharyngeal deposition

- This is the amount of inhaled steroid that does not enter the lung and is deposited in the oropharynx.

Table 4 shows the comparative results from the trials.

\section{Results from the trials}

None of the trials showed CIC to have any benefit over either FP or BUD for the outcomes of lung function, symptoms, quality of life, airway responsiveness to a provoking agent or inflammatory markers.

Lee, Fardon et al studied HPA suppression. At the end of each four week treatment period, of either CIC $800 \mathrm{mcg}$ bd or FP 1000 mcg bd, a 10 hour overnight urine collection (OUC) was taken and plasma cortisol response to a $100 \mathrm{mcg}$ bolus of hCRF was assessed at 30 and $60 \mathrm{~min}-$ utes. The authors state that data were logarithmically transformed to normalize the distribution but give no comment on how the data were skewed. Results comparing CIC and FP are reported as the geometric mean fold difference (GMFD) but there is no explanation as to how these values were calculated. By definition a GMFD of 1.0 means no difference.

When comparing the two treatments there was no significant difference in outcome with respect to plasma cortisol response to hCRF. However, there was significantly more suppression of urinary cortisol after FP than CIC (but with $95 \%$ CI of 1.1-2.0 this was only barely so). The results for plasma cortisol levels 60 minutes after hCRF are not reported in the table but the authors state that there was no significant difference between pretreatment and post treatment FP levels.

Two trials studied orpharyngeal deposition and were very similar in nature $[15,16]$. Nave et al compared CIC 800 mcg via a hydrofluoroalkane-pressurised metered-dose inhaler (HFA MDI) to BUD $800 \mathrm{mcg}$ via a chlorofluorocarbon-pressurised metered dose inhaler (CFC MDI). Richter et al compared CIC 800 mcg to FP 1000 mcg each via HFA MDI. Curves were plotted for recovery of each drug in rinsing solution against time after administration and then the molar area under the curve for $0-60 \mathrm{~min}$ utes $\left(\mathrm{AUC}_{0-60 \mathrm{~min}}\right)$ was calculated for $\mathrm{CIC}$, des-CIC and BUD (or FP) to allow direct comparisons.

The Nave et al study shows that the combined deposition of CIC and des-CIC in the oropharynx was less than half
(47\%) of that of BUD. Only $8 \%$ of the CIC deposited was converted into the active metabolite des-CIC (suggesting a lack of converting esterases in the oropharynx). Overall the concentration of des-CIC in the oropharynx $60 \mathrm{~min}$ utes after inhalation was only $4 \%$ of the BUD concentration (i.e. 25 times more BUD than des-CIC).

The Richter et al study shows that the combined deposition of CIC and des-CIC in the oropharynx was only $53 \%$ of that of FP. Furthermore only $17 \%$ of the CIC deposited was converted into the active metabolite des-CIC. The concentration of des-CIC in the oropharynx 60 minutes after inhalation was only $8 \%$ of the FP concentration (i.e. 12.5 times more FP than des-CIC).

\section{Discussion}

There are few data directly comparing CIC to other ICS and no published evidence directly comparing CIC to BDP specifically. None of the RCTs showed CIC to offer any benefit over BUD or FP for effectiveness i.e. none of the RCTs showed CIC to offer any benefit over BUD or FP for any patient based outcomes (asthma symptoms or QoL in these trials). Furthermore none of the trials demonstrated any benefit from CIC over BUD or FP for indirect outcomes of efficacy i.e. lung function, improving response to AMP or metacholine as provoking agents or for decreasing markers of inflammation.

All but one of the trials were sponsored by drug companies manufacturing CIC and seem to endeavour to demonstrate CIC to have equivalent efficacy to other ICS but with an improved safety profile. However, none of the studies report analyses which exclude superiority of one treatment over another (hence it is not possible to conclude that CIC was equivalent to FP or BUD for any efficacy outcomes) and the evidence regarding safety is not conclusive.

The conflicting evidence from the Lee, Fardon et al trial might indicate that $\mathrm{CIC}$ has less systemic adverse effects than FP. Challenges to this conclusion, however, are twofold. The first comes from the trial itself. This is the only published trial comparing HPA suppression between CIC and other ICS and the results were not unequivocal. There were also some methodological weaknesses in the trial. There was no evidence of concealment of allocation, an attrition rate of $30 \%$, no evidence of blinding other than the participants and the choice of a comparator (i.e. FP) that is reported to have the highest risk of side effects[10] (there is no published evidence directly comparing HPA suppression after treatment with CIC to either BUD or BDP).

The second challenge relates to the correlation between the intermediate outcome of HPA suppression measured 
Table 4: Summary of Results from RCTs Comparing Ciclesonide to Budesonide or Fluticasone

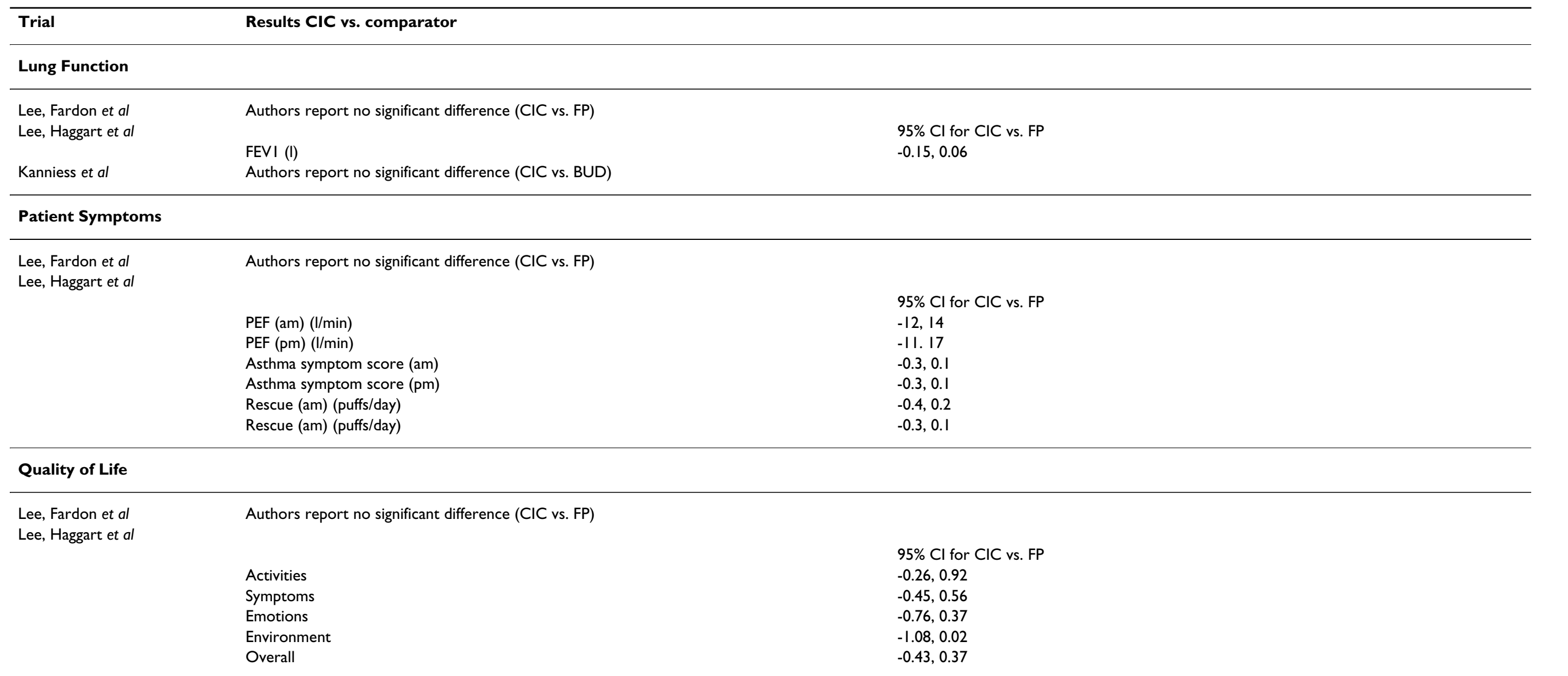

\section{Airway Responsiveness to Provoking Agent}

Lee, Fardon et al

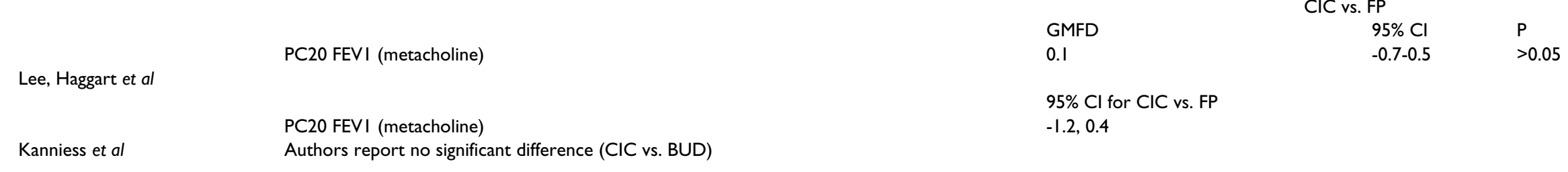

\section{Inflammatory Markers}

Lee, Fardon et al

GMFD

1.4

95\% Cl for ClC vs. FP
$\mathrm{CIC}$ vs. FP

$\begin{array}{ll}95 \% \mathrm{Cl} & \mathrm{P} \\ 0.8-2.5 & >0.05\end{array}$




\begin{tabular}{|c|c|c|c|c|c|}
\hline \multirow[b]{2}{*}{ Kanniess et al } & \multirow{2}{*}{$\begin{array}{l}\text { Exhaled Nitric oxide } \\
\text { Authors report no significant difference (CIC vs. BUD) }\end{array}$} & \multirow{2}{*}{\multicolumn{4}{|c|}{$-2.1,7.3$}} \\
\hline & & & & & \\
\hline \multicolumn{6}{|c|}{ HPA Suppression } \\
\hline \multicolumn{6}{|c|}{ Lee, Fardon et al } \\
\hline & & \multicolumn{3}{|c|}{$\mathrm{ClC}$ vs. FP } & \\
\hline & & GMFD & $95 \% \mathrm{Cl}$ & $P$ & \\
\hline & Cortisol pre-hCRF & 1.1 & $0.9-1.2$ & $>0.05$ & \\
\hline & Cortisol 30 mins post-hCRF & 1.0 & $0.9-1.2$ & $>0.05$ & \\
\hline & OUC & 1.5 & $1.1-2.0$ & $<0.05$ & \\
\hline \multicolumn{6}{|c|}{ Oropharyngeal Deposition } \\
\hline \multirow[t]{4}{*}{ Nave et al } & Test & Reference & $\begin{array}{l}\text { Point Estimates } \\
\text { of Molar } \\
\text { Adjusted } \\
\text { AUC0-60 min } \\
\text { Ratios }\end{array}$ & $95 \% \mathrm{Cl}$ & $P$ value \\
\hline & des-CIC & BUD & 0.04 & $0.02-0.05$ & $<0.0001$ \\
\hline & des-CIC & $\mathrm{ClC}$ & 0.08 & $0.06-0.11$ & $<0.0001$ \\
\hline & des-CIC + ClC & BUD & 0.47 & $0.38-0.59$ & $<0.0001$ \\
\hline \multicolumn{6}{|l|}{ Richter et al } \\
\hline & Test & Reference & $\begin{array}{l}\text { Point Estimates } \\
\text { of Molar } \\
\text { Adjusted } \\
\text { AUC0-60 min } \\
\text { Ratios }\end{array}$ & $95 \% \mathrm{Cl}$ & $P$ value \\
\hline & des-CIC & $\mathrm{FP}$ & 0.08 & $0.05-0.11$ & $<0.0000$ I \\
\hline & des-CIC & $\mathrm{CIC}$ & 0.17 & $0.13-0.22$ & $<0.00001$ \\
\hline & des- $\mathrm{ClC}+\mathrm{ClC}$ & FP & 0.53 & $0.40-0.69$ & $<0.001$ \\
\hline
\end{tabular}

at four weeks after the start of treatment with ICS correlates and clinically adverse effects for patients. HPA suppression is a well reported outcome of both short and long term ICS use [22-25]. However the clinical significance of such suppression is uncertain[6,22,25]. Current evidence suggests that ICS do not cause important systemic side effects in doses of up to $400 \mathrm{mcg} /$ day in children and $800 \mathrm{mcg} /$ day in adults,[26] and even in doses of more than $1 \mathrm{mg} /$ day there is no conclusive evidence that patients are at any increased risk from side-effects[25,23]. Hanania et al report HPA suppression and decreased bone density after regular use of conventional doses of ICS for asthma[24] but there is no conclusive evidence of a clinically adverse effect e.g. bone fractures.

Further long term studies are required to determine the long term risk of clinically significant adverse effects as a result of HPA suppression associated with ICS use in general and specifically with CIC. In the meantime it is not possible to conclude that CIC offers any benefit over other ICS in terms of systemic adverse effects.

With respect to local adverse effects there are similar challenges. Although, CIC might be expected to have fewer local adverse effects (due to the inhaled agent being its inactive metabolite des-CIC) there is no logical explanation why CIC should be deposited in the oropharynx in such smaller amounts than FP or BUD. In the Nave et al study the au point out that the difference in deposition could be due to the different inhaler de used. HFA MDIs have been shown to produce ICS with a smaller particle size than MDIs[27] resulting in $17 \%$ of a $200 \mathrm{mcg}$ dose of BUD being respirable[15] compar $48 \%$ of a $200 \mathrm{mcg}$ dose of CIC $[8,13]$. However, in the Richer et al study both inhalers HFA MDI and the authors make no mention of why deposition might be less given both treatments are inhaled via the same device. Neither trial was blinded in any which could have been a source of bias, and the lack of a logical explanation for vastly different deposition rates makes it difficult to draw any definite conclusion. Fu studies (preferably parallel) with larger populations are required before conclu whether CIC offers any benefit in terms of local adverse effects

In addition to the RCTs outlined above there are number of abstracts that have no been published as full papers. These trials involved substantially larger numbers of ticipants and ran for longer duration but have not been included in the analysis since contained insufficient detail for critical appraisal of methodological quality. The re reported in these abstracts do not alter the conclusions drawn from the full papers bu reported for interest in Appendix 1. 
Irrespective of any clinical benefit or not CIC is more expensive compared to BEC, BUD and FP as shown in Table 5. Treatment with CIC would come at substantial financial cost since at high dose (1000 mcg daily) CIC is 5.13 as expensive as BDP, 2.27 times as expensive as BUD (800 mcg daily) and 1.39 times as expensive as FP.

Any advantage that CIC might have over existing, cheaper, ICS is predicated on assertions regarding the long term dangers of ICS use. "Steroid phobia" is recognised in other fields[28] and is likely to form the basis for effective direct to patient marketing of $\mathrm{CIC}$, where such advertising is permitted. However, the evidence base on long term inhaled steroid use is far from certain and it is not clear whether the dangers are such that the precautionary principle is justified.

Although it is clear that the evidence base for ciclesonide will expand considerably with the publication of the larger studies excluded from this review, we believe it is important to highlight the limited nature of the evidence base that is currently available for scrutiny by clinicians and policy makers seeking to practice and support evidence based medicine.

\section{Conclusion}

There is very little evidence that has been published in full comparing CIC to other ICS. Current evidence is restricted to very small, phase II studies of low power. These demonstrate CIC has similar effectiveness and efficacy to FP and BUD (though equivalence is not certain) and findings regarding oral deposition and HPA suppression are inconclusive. There is no direct comparative evidence that CIC causes fewer side effects since none of the studies reported patient-based outcomes. Treatment with CIC would also come at substantial financial cost compared to other ICS.

\author{
Competing interests \\ $\mathrm{MD}$ - None \\ KS - None
}

$\mathrm{DH}$ has received sponsorship to attend international meetings and honoraria for lecturing, attending advisory boards and preparing educational materials from Altana, AstraZeneca, Boehringer Ingelheim, GlaxoSmithKline and Pfizer

\section{Authors' contributions}

KS and MD designed the study. MD performed the searches, retrieved papers, extracted data. MD and KS applied inclusion criteria, carried out the narrative synthesis and drafted the manuscript. DH participated in the design and coordination and helped to draft the manuscript. All authors read and approved the final manuscript. KS is guarantor.

\section{Funding}

No specific funding was received for the study.

MD's post in PenTAG was funded by the NHS Public Health Training Scheme (South West Region).

\section{Appendix I}

The search resulted in the retrieval of eight abstracts recorded in Table 6. The Hansel et al and Engelstatter et al abstracts had the same author group, trial characterists and results and were assumed to be from the same trial. Hence only one (Hansel et al) was included. The Fardon et al abstract appeared to be an abstract form of the Lee, Haggart et al full paper and hence the abstract was excluded. The Derom et al and Pauwels et al abstracts were identical in all ways other than that the former had 25 participants and the latter 26 . This could have been a typo-

Table 5: Cost of Inhaled Corticosteroids at various doses

\begin{tabular}{llll}
\hline ICS & Inhaler & Ex-valve Daily dose (mcg) & $\begin{array}{l}\text { Cost for 28 days treatment } \\
(\boldsymbol{(})\end{array}$ \\
\hline Beclomethasone & MDI & 100 & 1.29 \\
Beclomethasone & MDI & 400 & 2.28 \\
Beclomethasone & MDI & 1000 & 9.16 \\
Budesonide & Turbohaler & 100 & 2.05 \\
Budesonide & Turbohaler & 400 & 10.36 \\
Budesonide & Turbohaler & 800 & 20.72 \\
Fluticasone & HFA MDI & 100 & 2.53 \\
Fluticasone & HFA MDI & 500 & 19.84 \\
Fluticasone & HFA MDI & 1000 & 33.73 \\
Ciclesonide & HFA MDI & 100 & 6.66 \\
Ciclesonide & HFA MDI & 400 & 15.68 \\
Ciclesonide & HFA MDI & 1000 & 47.04 \\
\hline
\end{tabular}

Source: Department of Health Drug Tariff May 2005 
Table 6: Initial Retrieval of Trials Published as Abstracts

\begin{tabular}{|c|c|c|c|c|c|}
\hline Author & Date & Publisher & Sponsor & Comparator & Comments \\
\hline Boulet et al [29] & 2003 & $\begin{array}{l}\text { American.Journal of Respiratory.and } \\
\text { Critical.Care Medicine }\end{array}$ & ALTANA & BUD & \\
\hline Ukena et al [30] & 2003 & European Respiratory Journal & None declared & BUD & $\begin{array}{l}\text { Same as Biberger } \\
\text { abstract }\end{array}$ \\
\hline Engelstatter et al [3।] & 2003 & $\begin{array}{l}\text { American.Journal of Respiratory.and } \\
\text { Critical.Care Medicine }\end{array}$ & ALTANA & BUD & $\begin{array}{l}\text { Same as Hansel } \\
\text { abstract }\end{array}$ \\
\hline Biberger et al [32] & 2003 & $\begin{array}{l}\text { American.Journal of Respiratory.and } \\
\text { Critical.Care Medicine }\end{array}$ & ALTANA & BUD & $\begin{array}{l}\text { Same as Ukena } \\
\text { abstract }\end{array}$ \\
\hline Hansel et al [33] & 2003 & European Respiratory Journal & ALTANA & BUD & $\begin{array}{l}\text { Same as Engelstatter } \\
\text { abstract }\end{array}$ \\
\hline Fardon et al [34] & 2004 & Journal of Allergy and Clinical.Immunology & None declared & $\mathrm{FP}$ & $\begin{array}{l}\text { Same as Lee, Haggert } \\
\text { full paper }\end{array}$ \\
\hline Pauwels et al [35] & 2002 & $\begin{array}{l}\text { American.Journal of Respiratory.and } \\
\text { Critical.Care Medicine }\end{array}$ & ALTANA & $\mathrm{FP}$ & $\begin{array}{l}\text { Same as Derom } \\
\text { abstract }\end{array}$ \\
\hline Derom et al[36] & 2001 & $\begin{array}{l}\text { Oral presentation at European Respiratory } \\
\text { Society Annual Congress, September 22-26, } \\
\text { Berlin, Germany 200I }\end{array}$ & ALTANA & $\mathrm{FP}$ & $\begin{array}{l}\text { Same as Pauwels } \\
\text { abstract }\end{array}$ \\
\hline
\end{tabular}

graphical error and they were assumed to be abstracts of the same trial and only the Derom et al abstract included. The Biberger $e t$ al and Ukena et al abstracts had exactly the same author group, the same number of trial participants, the same trial and comparator doses but a slight difference in the results i.e. FEV1 increase after CIC and FP was 411 $\mathrm{ml}$ and $319 \mathrm{ml}$ respectively in Biberger et al and $416 \mathrm{ml}$ and $321 \mathrm{ml}$ respectively in Ukena et al with all other results the same. It was assumed that the data had been analysed differently in each case but that these results represented the same trial and only one (Ukena et al) was included. Table 7 shows details of the abstracts.

\section{Abstracts measuring lung function as end point}

- Ukena et al reported significantly greater improvement in both FEV1 and FVC after CIC compared to BUD (P < 0.0001 and $\mathrm{P}=0.0185$ respectively).

- Hansel et al did not demonstrate any significant difference between CIC over BUD.

- Boulet et al reported superiority of CIC over FP for FVC $(\mathrm{p}<0.01)$ but an insignificant difference for FEV1.

\section{Abstracts measuring patient symptoms as end point}

- Ukena et al reported no significant difference in asthma symptom improvement between CIC and BUD, although CIC did demonstrate earlier onset of treatment effect (three days versus two weeks).

- Hansel et al did not demonstrate any significant difference between CIC over BUD

- Boulet et al reported no significant difference in asthma symptom changes between CIC and FP although the per- centage of symptom free days was significantly higher in CIC vs. FP ( $43 \%$ vs. $43 \%$, p $=0.0288)$

\section{Abstracts measuring airway responsiveness to provoking agent as end point \\ - Derom et al reported no significant difference between CIC and FP for PC20 (AMP) FEV1}

\section{Abstracts measuring HPA suppression as end point}

- Ukena et al report no significant changes from baseline for urine cortisol levels for either CIC or BUD but do not compare the two treatments.

- Hansel et al report no significant changes from baseline for urine cortisol levels after CIC but a significant decrease after BUD. However they do not compare the two treatments.

- Derom et al report no significant changes from baseline for urine cortisol levels after CIC but a significant decrease after FP. However they do not compare the two treatments.

\section{Summary}

None of the results reported in the abstracts challenge the conclusions of the review.

\section{Acknowledgements}

None

\section{References}

I. Barnes PJ, Pedersen S: Efficacy and safety of inhaled corticosteroids in asthma. Report of a workshop held in Eze, France, October 1992. Am Rev Respir Dis 1993, I48:SI-26.

2. British guideline on the management of asthma. Thorax 2003, 58 Suppl I:i I-94. 
Table 7: Details of Abstracts (duplicates removed)

\begin{tabular}{|c|c|c|c|c|c|c|}
\hline Author & Date & Comparator & Study size & $\begin{array}{l}\text { Reported } \\
\text { characterists }\end{array}$ & Duration & Outcome Measures \\
\hline Boulet et al & 2003 & $\begin{array}{l}\text { CIC } 400 \mathrm{mcg} \\
\text { (mdi) od am } \\
\text { Vs. } \\
\text { BUD } 400 \mathrm{mcg} \\
\text { (turbo) od am }\end{array}$ & 359 & $\begin{array}{l}\text { Randomized } \\
\text { double blind } \\
\text { multicenter }\end{array}$ & 12 weeks parallel & $\begin{array}{l}\text { Lung function } \\
>_{\text {FEVI }} \\
>_{\text {FVC }} \\
\text { Symptoms } \\
>\text { Change in symptoms } \\
>\% \text { symptom free days } \\
>\text { use of rescue meds }\end{array}$ \\
\hline Ukena et al & 2003 & $\begin{array}{l}\text { CIC } 400 \mathrm{mcg} \\
\text { (mdi) od pm } \\
\text { Vs. } \\
\text { BUD } 400 \mathrm{mcg} \\
\text { (turbo) od pm }\end{array}$ & 399 & $\begin{array}{l}\text { Randomized } \\
\text { double blind } \\
\text { multicenter }\end{array}$ & 12 weeks parallel & $\begin{array}{l}\text { Lung function } \\
>\text { FEVI } \\
>_{\text {FVC, }} \\
\text { Timing of onset of action } \\
>_{\text {PEF }} \\
\text { Symptoms } \\
>\text { Change in symptoms } \\
>\text { \% symptom free days } \\
>\text { use of rescue meds } \\
\text { HPA Suppression } \\
>\text { Urine cortisol }\end{array}$ \\
\hline Hansel et al & 2003 & $\begin{array}{l}\mathrm{ClC} 100 \mathrm{mcg} \\
\text { (mdi) od am } \\
\text { Vs. } \\
\text { CIC } 400 \mathrm{mcg} \\
\text { (mdi) od am } \\
\text { Vs. } \\
\text { BUD } 200 \mathrm{mcg} \\
\text { (turbo) bd }\end{array}$ & 554 & $\begin{array}{l}\text { Randomized } \\
\text { double blind } \\
\text { multicenter }\end{array}$ & 12 weeks parallel & $\begin{array}{l}\text { Lung function } \\
>\text { FEVI } \\
>\text { FVC } \\
>\text { PEF } \\
\text { Symptoms } \\
>\text { Change in symptoms } \\
>\text { \% symptom free days } \\
>\text { use of rescue meds } \\
\text { HPA Suppression } \\
>\text { Urine cortisol }\end{array}$ \\
\hline Derom et al & 2001 & $\begin{array}{l}\text { CIC } 400 \mathrm{mcg} \text { od } \\
\text { Vs. CIC } 800 \mathrm{mcg} \\
\text { od } \\
\text { Vs. } \\
\text { CIC } 800 \mathrm{mcg} \text { bd } \\
\text { Vs. } \\
\text { FP } 500 \mathrm{mcg} \text { bd } \\
\text { Vs. } \\
\text { FP } 1000 \mathrm{mcg} \text { bd }\end{array}$ & 25 & $\begin{array}{l}\text { Randomized } \\
\text { double blind } \\
\text { double dummy } \\
\text { placebo controlled }\end{array}$ & $\begin{array}{l}7 \text { days } \\
6 \text { period crossover } \\
\text { with at least } 3 \\
\text { weeks washout } \\
\text { period }\end{array}$ & $\begin{array}{l}\text { Airway responsiveness to } \\
\text { AMP } \\
\text { PC20 FEVI(doubling doses) } \\
\text { HPA Suppression } \\
>\text { Plasma cortisol } \\
>\text { Urinary cortisol excretion }\end{array}$ \\
\hline
\end{tabular}

3. Eccles M, Rousseau N, Higgins B, Thomas L: Evidence-based guideline on the primary care management of asthma. Fam Pract 200I, I 8:223-229.

4. National Asthma Education and Prevention Program. Expert Panel Report: Guidelines for the Diagnosis and Management of Asthma Update on Selected Topics--2002. J Allergy Clin Immunol 2002, I I 0:SI 4 I-S2 19.

5. Tattersfield AE, Knox AJ, Britton JR, Hall IP: Asthma. Lancet 2002, 360: $1313-1322$.
6. Allen DB, Bielory L, Derendorf H, Dluhy R, Colice GL, Szefler SJ: Inhaled corticosteroids: past lessons and future issues. J Allergy Clin Immunol 2003, I I 2:SI-40.

7. Weinbrenner A, Huneke D, Zschiesche M, Engel G, Timmer W, Steinijans VW, Bethke T, Wurst W, Drollmann A, Kaatz HJ, Siegmund $\mathrm{W}$ : Circadian rhythm of serum cortisol after repeated inhalation of the new topical steroid ciclesonide. J Clin Endocrinol Metab 87:2160-2163. 
8. Rohatagi S, Appajosyula S, Derendorf H, Szefler S, Nave R, Zech K Banerji D: Risk-benefit value of inhaled glucocorticoids: a pharmacokinetic/pharmacodynamic perspective. J Clin Pharmacol 2004, 44:37-47.

9. Jackson LD, Polygenis D, Mclvor RA, Worthington I: Comparative efficacy and safety of inhaled corticosteroids in asthma. Can J Clin Pharmacol 1999, 6:26-37.

10. Adams N, Bestall JM, Lasserson TJ, Jones PW: Inhaled fluticasone versus inhaled beclomethasone or inhaled budesonide for chronic asthma. Cochrane Database Syst Rev 2004:CD0023I0.

II. Compendium EM: Alvesco Product Information. Electronic Medicines Compendium 2005 [http://emc.medicines.org.uk/emc/assets/c/ html/displaydoc.asp?documentid=15768].

12. Belvisi MG: Preclinical pharmacology of ciclesonide. European Respiratory Review 2004, 13:66-68.

13. Rohatagi S, Arya V, Zech K, Nave R, Hochhaus G, Jensen BK, Barrett JS: Population pharmacokinetics and pharmacodynamics of ciclesonide. J Clin Pharmacol 2003, 43:365-378.

14. Nave R, Bethke TD, van Marle SP, Zech K: Pharmacokinetics of [I4C]ciclesonide after oral and intravenous administration to healthy subjects. Clin Pharmacokinet 2004, 43:479-486.

15. Nave R, Zech K, Bethke TD: Lower oropharyngeal deposition of inhaled ciclesonide via hydrofluoroalkane metered-dose inhaler compared with budesonide via chlorofluorocarbon metered-dose inhaler in healthy subjects. Eur J Clin Pharmacol 2005.

16. Richter K, Kanniess F, Biberger C, Nave R, Magnussen H: Comparison of the oropharyngeal deposition of inhaled ciclesonide and fluticasone propionate in patients with asthma. J Clin Pharmacol 2005, 45: I 46-I52.

17. Lee DK, Fardon TC, Bates CE, Haggart K, McFarlane LC, Lipworth B]: Airway and systemic effects of hydrofluoroalkane formulations of high-dose ciclesonide and fluticasone in moderate persistent asthma. Chest 2005, 127:85I-860.

18. Lee DK, Haggart K, Currie GP, Bates CE, Lipworth BJ: Effects of hydrofluoroalkane formulations of ciclesonide $\mathbf{4 0 0}$ microg once daily vs fluticasone $\mathbf{2 5 0}$ microg twice daily on methacholine hyper-responsiveness in mild-to-moderate persistent asthma. Br J Clin Pharmacol 2004, 58:26-33.

19. Kanniess F, Richter K, Bohme S, Jorres RA, Magnussen H: Effect of inhaled ciclesonide on airway responsiveness to inhaled AMP, the composition of induced sputum and exhaled nitric oxide in patients with mild asthma. Pulm Pharmacol Ther 200I, 14:141-147.

20. Juniper EF, Guyatt GH, Cox FM, Ferrie PJ, King DR: Development and validation of the Mini Asthma Quality of Life Questionnaire. Eur Respir J 1999, 14:32-38.

21. Schlaghecke R, Kornely E, Santen RT, Ridderskamp P: The effect of long-term glucocorticoid therapy on pituitary-adrenal responses to exogenous corticotropin-releasing hormone. $\mathrm{N}$ Engl J Med 1992, 326:226-230.

22. Wolthers OD, Honour JW: Measures of hypothalamic-pituitary-adrenal function in patients with asthma treated with inhaled glucocorticoids: clinical and research implications. $J$ Asthma 1999, 36:477-486.

23. Hanania NA, Chapman KR, Kesten S: Adverse effects of inhaled corticosteroids. Am J Med 1995, 98:196-208.

24. Hanania NA, Chapman KR, Sturtridge WC, Szalai JP, Kesten S: Doserelated decrease in bone density among asthmatic patients treated with inhaled corticosteroids. J Allergy Clin Immunol 1995, 96:57I-579.

25. Barnes NC: Safety of high-dose inhaled corticosteroids. Respir Med 1993, 87 Suppl A:27-31.

26. Warrell DAE: Oxford Textbook of Medicine. 2003, 2:.

27. Leach CL, Davidson PJ, Hasselquist BE, Boudreau RJ: Lung deposition of hydrofluoroalkane-134a beclomethasone is greater than that of chlorofluorocarbon fluticasone and chlorofluorocarbon beclomethasone : a cross-over study in healthy volunteers. Chest 2002, 1 22:510-516.

28. Garside R, Stein K, Castelnuovo E, Pitt M, Ashcroft D, Dimmock P, Payne $L$ : The effectiveness and cost-effectiveness of pimecrolimus and tacrolimus for atopic eczema: a systematic review and economic evaluation. Health Technol Assess 2005, 9:iii, xi-iii,230.

29. Boulet LP, Engelstatter R, Magyar P, Timar M, Knight A, Fabbri L: Ciclesonide is at least as effective as budesonide in the treat- ment of patients with bronchial asthma [abstract]. American Thoracic Society 99th International Conference 2003:CI05.

30. Ukena D, Biberger C, Von BV, Malek R, Weber HH, Beck E, Linnhoff A: Ciclesonide significantly improves pulmonary function when compared with budesonide: a randomised 12 week study [Abstract]. European Respiratory Journal 2003, 22:.

31. Engelstatter R, Benezet O, Kafe H, Ponitz HH, Hansel T, Cheung D, Steinijans VW, Barnes PJ: Comparative study in asthma patients treated with inhaled ciclesonide (80\&micro;g or $320 \&$ micro;g once daily) or budesonide (200\&micro;g twice daily) for 12 weeks [abstract]. American Thoracic Society 99th International Conference 2003: CI05.

32. Biberger C, Von BV, Malek R, Weber HH, Beck E, Linnhoff A, Ukena $D$ : Efficacy and safety of ciclesonide compared with budesonide in asthma patients: a randomized |2-week study [abstract]. American Thoracic Society 99th International Conference 2003:C105.

33. Hansel T, Engelstatter R, Benezet O, Kafe H, Ponitz HH, Cheung D, Barnes PJ: Once daily ciclesonide (80ug or $320 \mathrm{ug}$ ) is equally effective as budesonide 200ug given twice daily: a 12 week study in asthma patients [Abstract]. European Respiratory Journal 2003, 22:

34. Fardon TC, Lee DK, Gray RD, Currie GP, Haggart K, Bates CE, Lipworth BJ: Effects of hydrofluoralkane formulations of ciclesonide $320 \&$ micro;g once daily versus fluticasone propionate 220\&micro;g twice daily on methacholine hyperresponsiveness in mild-to-moderate persistent asthma [Abstract]. Journal of Allergy and Clinical Immunology 2004, I I 3:SI I 9.

35. Pauwels R, Derom E, Van DVV, Marissens S, Vincken W: Effects of inhaled ciclesonide and fluticasone propionate on cortisol secretion and PC20 for adenosine in asthma patients [abstract]. American Journal of Respiratory and Critical Care Medicine 2002, 165:A768.

36. Derom E, Van DVV, Marissens S, Vincken W, Pauwels RA: Efficacy and systemic effects of ciclesonide and fluticasone in asthma patients. European Respiratory Journal 2001, 18:147s.

\section{Pre-publication history}

The pre-publication history for this paper can be accessed here:

http://www.biomedcentral.com/1471-2296/7/34/prepub
Publish with Bio Med Central and every scientist can read your work free of charge

"BioMed Central will be the most significant development for disseminating the results of biomedical research in our lifetime. "

Sir Paul Nurse, Cancer Research UK

Your research papers will be:

- available free of charge to the entire biomedical community

- peer reviewed and published immediately upon acceptance

- cited in PubMed and archived on PubMed Central

- yours - you keep the copyright
BioMedcentral 